\title{
THE INFLUENCE OF ONLINE LEARNING ON STUDENTS' CHARACTERISTICS
}

\author{
Rudy $^{1}$ \\ Universitas Prima Indonesia, Medan, Indonesia \\ e-mail: rudyl@unprimdn.ac.id \\ Widya Silalahi' ${ }^{2}$ \\ Universitas Prima Indonesia, Medan, Indonesia \\ e-mail: widyasilalahi88@gmail.com \\ Tuti Farida R. Sinaga ${ }^{3}$ \\ Universitas Prima Indonesia, Medan, Indonesia \\ e-mail:tutyfarida99@gmail.com
}

\begin{abstract}
During the pandemic time, almost all educational institutions implement online learning system for their students. This research aims at identifying the concept of online learning and analyzing the types of characteristics that can be formed through online learning. It is expected to contribute as a complement of theory in the fields of humanities, social sciences, and education. It can also be additional material for researchers who are interested in the topic of online learning. The data were obtained from the questionnaire responded by 22 students of the the $6^{\text {th }}$ semester (morning class $E$ ) of FKIP UNPRI Medan and the reviewing of a number of relevant literature. As a conceptual analysis study, the data were analyzed by using representation theory to interpret the concept of online learning and its impact which could symbolize certain meanings. The result of analysis suggested that the term "online learning" can basically be conceptualized as a learning system emphasizing freedom which could show efficiency and innovation. The result of analysis also revealed that there were three types of characteristics - curiosity, facing challenges and a sense of responsibility that can be formed as a result of online line study which is considered to contribute to character building.
\end{abstract}

Keywords: online learning, characteristic, character building, concept of online learning 
Vol. 3 No. 2

December 2021

e- ISSN 2685 - 0559

p- ISSN 2684 - 673X

\section{INTRODUCTION}

In March 2020, a disease called COVID-19 and had never before infected humans (Yuliana, 2020, p. 187) began to spread widely to many countries in the world. This has caused many problems to the world for example, death rates insufficient number of medical personnel, the rise of unemployment, the decline in economy etc. One of the aspects that has also been affected is education. It has caused a complex problem in the world of education (Pokhrel \& Chhetri, 2021, p. 133). Generally, online learning as the name implies is the study conducted by using computer and the Internet connection to broaden student's knowledge (Baig, 2011, p. 28). In other words, people who study online do not have to come to class. Online learning is not something new in the world of education. However, when in-class learning is totally replaced by online learning, various effects will arise.

Online learning has widely been applied in schools and academic institutions during the pandemic period because many countries have postponed in-class education (Abidah et al., 2020, p. 38). This means, online learning has been popularly conducted as a way of study to minimize the spread of infectious disease. However, online learning that is undertaken by school and college students can bring certain changes. One of them is the impact on their characters. It is true that people's characters can be influenced by the surroundings.
Learning and teaching activity can indeed have an influence on the formation of a person's character (Marini, 2017, p. 117; Ratnasari, 2018 , p. 34). It is necessary to realize that in fact, something new that someone does can contribute to their characteristics. Since a person's character plays an important role in their life, people need to know that certain conditions they experience can have an impact on their character.

For instance, the online learning which is totally applied in schools and campuses can be something new for school and college students. Moreover, the pandemic situation requires people to do online learning. By relating character building to the online learning carried out by people during the pandemic time, this discussion can become a significant as well as interesting study to conduct. this research has two objectives - to identify the concept of online learning and to figure out the types of characteristics that can be formed through online learning.

There are at two purposes to fulfill in this research. First, theoretically, the result of the study can be considered as contribution to the development of theory in education field. This means the findings of this study are useful to complete existing theories in educational studies as well as other relevant fields such as media studies, cultural studies, psychology, etc. Practically, this study can help improve people's understanding 
Vol. 3 No. 2

December 2021

e- ISSN 2685 - 0559

p- ISSN 2684 - 673X

about the relation between online study and character formation so that people can do the right thing in conducting online learning. Additionally, this research can help parents, students, teachers, and academicians to pay more attention to characters development during the online learning period. The online learning discussed in this study refers to a learning system that utilizes the Internet implemented in schools. In other words, this study limits the discussion within the scope of the college students because online learning has become an inevitable choice during the pandemic time. In other words, by using conceptual analysis, this study discusses the impact of online learning on character building in people who carry out online learning regularly, for example, school and university students.

\section{LITERATURE REVIEW}

Since this study discusses about the effect of online learning on student's characteristics, it is essential to understand the term 'character' used in this study. People need to understand that character can be formed. It can developed through education (Dwirahayu, 2011, p. 131). This means, a person's characteristic can change. The characteristics that undergo these changes refer to the term 'character building' used in this study. It also mean "a set or a group of characteristics". An important term to clarify is 'character'. To clearly define what 'character' means, the meaning indicated by the dictionary can provide an appropriate explanation. In dictionary, 'character' can have many meanings. Among the meanings of 'character' listed in Oxford Advanced Learner's Dictionary, the meaning of 'character' that is suitable in this study is that 'character' means "all the qualities and features that make a person, groups of people, and places different from others"(Wehmeier, 2000, pp. 195196). From the definitions above, the term 'character' appears in this study can refer to a set of characteristics of a person.

While the term 'online learning' used in this study refers to the process of distance learning (carried out by school or college students) using the Internet. This kind of leaning occurs when certain circumstances in a society or country do not allow face-to-face learning. Further discussion of the online learning concept is presented in the analysis section.

A literature review has been carried out by observing several researches on online learning, for instance, Simon's work in 2012 discussed about the role of technology in the process of forming a professional identity in higher education. There was also a study conducted by Xu and Jaggers (2013) which compared online learning and physical learning as well as its quality. Several studies from Indonesian researchers such as Yusnilita (2020), Nambiar (2020), Abidah et al. (2020) and Maulana (2021) specifically focused on the 
Vol. 3 No. 2

December 2021

e- ISSN 2685 - 0559

p- ISSN 2684 - 673X

impact of online learning on student's achievement, satisfaction, and psychological effects such as stress and anxiety as well as the implementation of certain programs in online learning. Although those researches also talked a little about the relationship between online learning and student's characteristics, the discussion has not specifically and thoroughly concentrated on the formation of characteristics. Therefore, this study can fill this gap by focusing on the impact of online learning on the formation of student's characteristics.

\section{RESEARCH METHOD}

This study is a research conducted by collecting data from the third year (semester $6^{\text {th }}$ ) students of the faculty of teaching and education in Universitas Prima Indonesia and supported by literature related to the discussed issue. In general, this study focuses more on collecting library sources. This kind of study requires researchers to gather as much information as possible that they are going to use in their research (Giarrusso et al., 1994, p. 84). Additionally, Hasan (2002, p. 11) explains, this kind of research usually uses references such as books, journal, scientific reports, theses, dissertations, and others, as the main source to obtain the needed for the research. In this digital era, source of information can be acquired through the Internet such as e-books, e-journal, and so on. Commonly, researches in the humanities field or social sciences such as literary and cultural studies, media studies, etc. often apply qualitative research (Glaser \& Strauss, 1967, p. 18). This type of research tends to examine and understand certain phenomena in human behavior and their interactions in certain circumstances based on the researcher's analysis (Usman \& Akbar, 2008, p. 79). Qualitative research can use behavior patterns, perspectives, norms, or events in social life as data for research (Ahimsa-Putra, 2009, p. 18). Thus, the data obtained in qualitative research is not in the form of numbers or percentages, but rather in the form of statement or a set of explanations.

The main data were obtained from the results of questionnaires filled out by 22 respondents (4 male and 18 female students). They were the $6^{\text {th }}$ semester morning class $E$ students from the Faculty of Teaching and Education in Universitas Prima Indonesia, Medan. Since this study tends to examine concepts, other essential data were gathered from references related to the object of discussion in this study. By this way, the acquired were analyzed or interpreted to generate findings which can solve the research problems. The findings of this study are based on the data that has been collected during the research process. So, the research data consists of the data from the questionnaire and library research data (source of literature) closely related to the object of the study. Basically, this study can be 
Vol. 3 No. 2

December 2021

e- ISSN 2685 - 0559

p- ISSN 2684 - 673X

categorized as conceptual analysis because it emphasizes the conceptualization of terms so that it can be understood more specifically. To help construct the concept, a theory of representation is needed to interpret the terms discussed in this study. The data obtained from the research is in the form of statements about the issue discussed in the study. Those statements are considered as symbols which can show a thing, persons, occurrences, etc. (Hall, 1997, p. 28; Chandler, 2007, p. 13). Most studies in the social and cultural sciences, various phenomena can be perceived as symbols that can be interpreted. The collected data can be classified based on the discussions. Then, each data that has been assigned to its category will be analyzed to generate research findings based on the problems discussed in this study.

\section{RESULT AND DISCUSSION}

The result of analysis suggests that the concept of online learning actually needs to cover a broad range of things. Additionally, the result of the study also reveals that online learning can shape certain kinds of characteristics. First of all, it is essential to see the relationship between online learning and the formation of characteristics. Student's characteristic will be affected by the learning and teaching process and the subjects they learn (Marini, 2017, p. 117). It can be interpreted that besides the system of learning and the learning materials, the teaching process also plays an important role. The results of data collection through questionnaires could show that almost $70 \%$ of the total 22 respondents were sure that online learning had an impact on the formation of a person's characteristics, especially students.

Therefore, According to Ratnasari (2018, p. 27) educators have a role in shaping student's characteristic. Based on the understanding of the relationship between online learning and the formation of characteristics, in online learning period where students and teachers do not meet face-to-face, there is still a significant influence on students in general. In other words, online learning can have an impact on the character of learners, especially the formation of certain characteristics that are able to provide positive values in everyday life. From the results of the search for library resources and reference review analysis about the relationship between online learning and character building, there are at least three characteristics of learners that can be formed through the online learning process. As followings:

\subsection{Curiosity}

The first characteristic discusses in this section is curiosity. Respondents were asked to tick the answer to the question whether online learning could develop their curiosity. The answers from the respondents are shown in the bar chart below: 


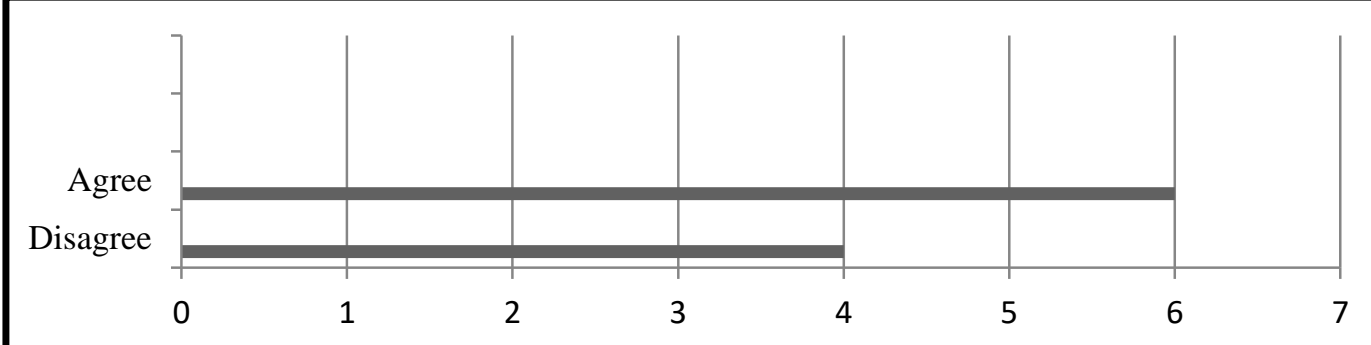

Figure 3.1. Responses about the Effect of Online Learning on the Formation of Curiosity

Data obtained from the questionnaires filled out by 22 respondents showed that there were 14 respondents (about 60\%) who agreed that online learning could trigger their curiosity and 8 respondents (about 40\%) said no. The result of questionnaire revealed that the $6^{\text {th }}$ semester students of the Faculty of teaching and education, UNPRI had a thought that online learning could make them grow their curiosity Although this study has not yet shown what they were curious about. However, this data can at least give an idea that the online learning system by using the sophistication of technology and social media can arouse curiosity.

Everyone may feel curious about something, be it something new or something that is old but still needs to be explored more deeply. The meaning of curiosity cannot be conceptualized with only one point of view because its meaning is broad and can be related to being creative and open to things that one experiences (Rowson et al., 2012, p. $3)$. This explanation leads to an understanding that there are essential elements such as creativity and openness to knowledge behind curiosity. Therefore, it is obvious that curiosity can be connected to learning, for instance, conventional learning system, distance learning, etc. For this reason, according to Graham \& Helen (2011, p. 26) there are many researches which can prove that curiosity plays an essential role in learning, particularly in education.

In general, people tend to think that being curious is related to a good characteristic (Borowske, 2005, p. 346). This can be understood that people who are curious will look for ways to find answers to questions that make them curious. The effort to search for ways out to something that makes people curious will good characteristic in learning. Regarding the virtue of curiosity, it can be interpreted as a trait of wanting to get details of something and this kind of trait is indeed necessary for a learner to have (Olson, 1986, p. 27; Markey \& Loewenstein, 2014, p. 228). This can be interpreted that someone who has curiosity will have gain broader knowledge. So, curiosity in a positive way can be perceived as the basis for learning.

Since curiosity may represent willingness to seek information and knowledge, it can clearly be seen that curiosity can be related to 
Vol. 3 No. 2

December 2021

e- ISSN 2685 - 0559

p- ISSN 2684 - 673X

online learning. The relationship between these two things can be viewed from the impact on a learner. Someone who conducts online learning is believed to develop this curiosity towards various phenomena that occur around him or things related to him. Therefore, it is an essential characteristic in learning because according to Mohanty, Pradhan \& Jena $(2015$, p. 2) curiosity encourages a person to gain knowledge and experience that occurs continuously.

It is true that online learning can be seen as an effect of the rapid development of technology, especially the increasing use of the Internet. This has paved the way for the growth of various kinds of innovations related to learning such as social media platforms, websites, virtual meeting applications and so on that exist to meet the needs of students to obtain the knowledge and information that they need. All of this gives students an ample opportunity to explore different kinds of sources from the Internet to find out about the various things they need to know. This will lead them to curiosity. Regarding this, according to Borowske (2005, p. 347) there is a study conducted by Daniel Berlyne which suggests that here is a general curiosity such as seeking for something new, dealing with risky things, adventuring, etc. and there is also a specific curiosity, for example research some phenomena or problems so that they can be understood and learned.
A curious student is always characterized by his activeness in class. This has also been revealed by Olson (1986, p. 27) that curious students always show a tendency to ask more questions with more qualified questions and know more about the life around them as well as remember many facts in detail. The world of information technology (IT) and everything that can be accessed by the Internet is a vast knowledge. Therefore, students who rely on online learning can use the Internet to satisfy their curiosity about something. This is also pointed out by Gülten et al. (2011, p. $249)$ that curiosity can be perceived as a fundamental factor in matters relating to information technology created by humans. Science and technology will also develop if humans have high curiosity. With the presence of an online learning system that utilizes technological sophistication, students can get to know the cyberspace gradually. This condition may encourage them to explore more knowledge with the support of growing Internet access. For this reason, the application of online learning system in education institutions may help students grow their sense of curiosity.

The exploration of the world of IT and cyberspace will never end because science and technology will continue to advance. This has a big impact on the online learning system which will also continue to develop so that it can raise and increase curiosity in people who conduct online learning. From the explanation above, it can be 
Vol. 3 No. 2

December 2021

e- ISSN 2685 - 0559

p- ISSN 2684 - 673X

understood that online learning can trigger students to generate and cultivate curiosity by exploring virtual world that provides various kinds of information and knowledge for learning. However, if this cannot be carefully filtered by them (particularly adolescent students or children), negative impact will arise.

\subsection{Facing Challenges}

The next characteristic that can be developed through online learning activities is facing challenges. It is in the context of exploring the world of knowledge by using an online learning system. Utilizing technology and Internet access for learning is something that cannot be ignored because of the increasingly rapid growth of technology in the digital era. Today is known as the era of digitalization which has a huge impact on almost all aspects of human's life, including the learning system applied in educational institutions around the world.

This condition can create a challenging opportunity for those who study online. Only about $20 \%$ of the respondent agreed that online learning could be considered as something scary rather than challenging. There were also about $20 \%$ who did not give comments. So there were 18 out of 2 respondents who perceived online learning as a challenge that they had to face. This small scale research may at least illustrate that the use of technology for distance learning is still considered by many students as challenging.

\begin{tabular}{|c|c|c|}
\hline Respondents & Percentage & Response \\
\hline 18 students & $60 \%$ & Online learning is seen as something challenging. \\
\hline
\end{tabular}

Table 3.2. Responses to Online Learning as a Challenge

This is called challenging because online learning system is totally different from traditional inclass learning system in terms of the process of interaction between students and instructors or fellow students (Vonderwell \& Savery, 2004, p. 39). This condition also becomes more challenging when all students are required to do online learning totally due to the ongoing pandemic situation around the world. According to Nichols et al. $(2008$, p. 1$)$ it is said that in fact the learning and teaching process that relies on technology is closely related to the way of learning based on challenges This can be interpreted that online learning can be considered as a challenge for students. People who study online tend to be involved in the process of exploring technology. In other words, people will always feel challenged when facing with technological development. This happens due to the demands of the digital era which encourage people to learn to use technology, including online learning.

When it comes to online learning, there are people who are familiar with the online learning will be challenged to find out more new things about it. There are also people who are not too familiar with 
Vol. 3 No. 2

December 2021

e- ISSN 2685 - 0559

p- ISSN 2684 - 673X

the Internet will feel challenged to know more about online learning, too. Both types of people will see this condition as a challenge. This challenge is not only experienced by students, but many teachers also see online learning system as a challenge that they must face and learned in order to convey learning materials effectively and comfortably. For instance, Irfan et al. (2020, p. 151) conducted a study which showed that Indonesian teachers who taught online had never received training in using online learning platforms before, but they felt challenged to learn it.

So, situations that require students to use online learning system such as during the current pandemic make everyone dependent on technology to learn or to deal with the daily work. It grows some kind of characteristic to be ready to face challenges in any kinds of forms. Dependence on online learning seems to be a challenge for everyone in the education field, not only in terms of the use of technology, encouragement, but also in terms of Internet connections (Aini et al., 2020, p. 3). In other words, there are various challenges will definitely be faced by students in online learning.

Each student can experience different challenging things in online learning and this condition will form a certain characteristic in students, an attitude that is ready to face challenges. Teachers and students, including those who are used to and those who are not familiar with online learning are forced to carry out an online learning system, especially during the pandemic time. Thus, according to Mahyoob (2020, p. 359) they seem to have no other choice but to face these challenges, to learn how to use certain new programs and try to overcome the problems.

Even though each student and institution may have a different kinds of perception on challenges, challenge is still a complicated thing to conceptualize (St.Clair \& Hackett, 2012 , p. 114). Therefore, it someone sees a situation as something that he or she must be able to handle, then it can be perceived as a challenge. This will somehow raise a spirit for him to go through it. The same thing can also be seen from online learning. The various kinds of challenges that students have to face during the pandemic period make most of them people who have the characteristics to accept challenges, especially in terms of online learning where there are a number of challenges they need to face.

Regardless of any challenges faced by those who conduct online learning, the trait that shows readiness in facing challenges can be perceived as a positive characteristic that a student needs to have to overcome various kinds of difficulties in his daily life. So, technology used in education, such as online learning system may offer teachers a new method of presenting teaching materials to their students and this will also have an impact on students in terms of forming readiness to face challenges 
Vol. 3 No. 2

December 2021

e- ISSN 2685 - 0559

in online learning. Related to the formation of an attitude of accepting challenges, according to Sareen \& Nangia (2020, p. 3017) in general, many teachers think that they can teach better during in-class learning. However, this condition can actually encourage teachers to overcome these challenges so that they can do online teaching as well as they teach in the classroom.

\subsection{Responsibility}

The result of study also suggested that most of the respondents agreed that online learning could foster their sense of responsibility. This can be seen from the results of data collection from questionnaires involving 22 student respondents. There were 14 respondents said that the online learning system could make a person more responsible. Meanwhile, about 8 respondents said that there was no relationship between online learning and responsibility. By taking the answer from the most respondents, it can be underlined that they think that the online learning they are conducting during the pandemic time can shape and strengthen their nature of responsibility. In other words, online learning may contribute to the formation of responsible characteristic.

Responsibility is a characteristic that everyone needs to have, especially students. The sense of responsibility is significant in social life (Martin, 2007, p. 21) because every individual must do something every day. According to Green
(1943, p. 392) if a person does not have responsibility for what he or she does, then rights and obligations cannot be carried out properly. This means that everyone must be responsible for everything he or she does. If this is relate to learning, then, a student must be responsible for his study. Responsibility can be interpreted that a person must be able to consider the things he or she does, its consequence, conditions, duties, and others in front of the person who gives the task to him or her (Lenk \& Maring, 1999, p. 53). From the explanation above, it can be interpreted that a sense of responsibility is closely related to ethical behavior in everyday life.

There is an assumption that online learning seems more relaxing and not as rigid as in-class learning. This opinion may be true for some people. However, in reality, students who conduct online learning must be able to fulfill their obligations to study online and complete the tasks given by lecturers through certain social media platforms. This is not an easy thing to do if a student does not have a sense of responsibility. So, being responsible is a good thing. People who have a sense of responsibility usually care about their tasks and will not approve of sloppy work in order to avoid mistakes and problems (Martin, 2007, p. 21). In terms of online learning, many students will be trained to be responsible for their study. They will have to motivate themselves to do their duties.

Responsibility can be perceived in different ways. The concept of 
responsibility discussed in this part is the responsibility related to obligations and morals as explained by Martin (2007, p. 27) that the concept may cover the responsibility for tasks, work, etc. and another one is the responsibility for someone or something which is generally understood by most people. Additionally, the meaning of responsibility is broad because it does not only refer to the person who is responsible for something but it also includes the idea of evaluation in terms of carrying out tasks (Lenk \& Maring, 1999, p. 53).

Regarding the concept of being responsible, Allan (2006, p. 179) in his study found that in the world of education, students tend to associate being responsible with obedient behavior in class, for instance showing activeness in learning and participating in team working. From the explanation above, it can be understood that the sense of responsibility that students have in conducting online learning is related to their success in carrying out their obligations as students, for instance, attending virtual meetings with lecturers, working on and submitting assignments, studying the material provided by the lecturers online, participating the exams, completing their administrative files, and so on. All those things cannot be done in person (face-to-face) and must be done online because the whole world is facing the serious pandemic situation. This condition forces them to take responsibility for themselves for the success of their study during the pandemic time. This can trigger their sense of responsibility in learning.

To sum up, from the results of the analysis and discussion above, it is obvious that the online learning system implemented in almost all schools in the world, especially in Indonesia during the COVID-19 pandemic can have an influence on students' characteristics. Since online learning system is the result of the advance growth of technology and the use of Internet, many of the students become curious about new things they need to explore in the IT world and this can develop their curiosity. This condition will make them think that online learning is a challenge because the system is different from in-class (face-to-face) learning system that cannot be conducted during the pandemic. Therefore, they will prepare or be ready to face various challenges related to online learning system with all its complexity. That way, students can develop their sense of responsibility so that they can continue to attend lecturers and complete their study.

\section{CONCLUSION}

From the results of the discussion and analysis in this study, there are four important points which can be concluded. First, "online learning" which is the essential term used in this study can be conceptualized from various perspectives. One of the concept of online learning is by focusing on the element of freedom in an online learning system that can reflect the 
Vol. 3 No. 2

December 2021

e- ISSN 2685 - 0559

p- ISSN 2684 - 673X

significance of efficiency and innovation in it.

Second, the results of analysis suggest that online learning carried out by students can have an impact on the formation of their characteristics. It can encourage their curiosity. This is related to the online learning system which is still considered a new method by many students in Indonesia. Therefore, by this system, they will be curious to find out and study about it.

Third, online learning can also be considered as something challenging. Before he pandemic time, the system applied was in-class learning which is totally different from the online learning system which comes with a number of complexities such as Internet access, the ability to use social media platforms for learning, and so on. This makes online learning more challenging and will shape the nature of preparedness among in students, especially when it comes to the problems in the IT world. Finally, the result of discussion also suggests that the implementation of online learning system can also have an influence on the formation of a sense of responsibility in students for continuing and completing their study.

\section{REFERENCES}

Abidah, A., Hidaayatullaah, H. N., Simamora, R. M., Fehabutar, D., \& Mutakinati, L. (2020). "The Impact of Covid-19 to Indonesian Education and Its Relation to the Philosophy of 'Merdeka Belajar.'" Studies in

Philosophy of Science and Education, 1(1), 38-49. https://doi.org/10.46627/sipose .v1i1.9

Ahimsa-Putra, H. S. (2009). Paradigma Ilmu Sosial-Budaya: Sebuah Pandangan. Paper

presented at Kuliah Umum Paradigma Penelitian IImu-IImu Humaniora UPI,

Bandung.

Aini, Q., Budiarto, M., Putra, P. O. H., \& Rahardja, U. (2020). "Exploring E-learning Challenges During the Global COVID-19 Pandemic." Jurnal Sistem Informasi, 16(2), 57-65. https://doi.org/10.21609/jsi.v16 i2.1011

Allan, G. M. (2006). Responsibility for Learning: Students' Understandings and Their SelfReported Learning Attitudes and Behaviors. Unpublished master's thesis. Queensland University of Technology, Brisbane.

Appana, S. (2008). "A Review of Benefits and Limitations of Online Learning in the Context of the student, the instructor, and the Tenured Faculty". International journal of $E$ Learning 7 (1): 5-22.

Baig, M. A. (2011). "A Critical Study Of Effectiveness of Online Learning On Students Achievement." I-Manager's Journal of Educational Technology, 7(4), 28-34. https://doi.org/10.26634/jet.7.4 .1391

Borowske, K. (2005). Curiosity and Motivation-to-Learn. ACRL 
Vol. 3 No. 2

December 2021

e- ISSN 2685 - 0559

p- ISSN 2684 - 673X

Twelfth National Conference, Minneapolis, Minnsota.

Chandler, D. (2007). Semiotics: The Basics (2nd ed.). New York: Routledge.

https://doi.org/10.1016/S03782166(02)00176-5

Dhull, I. \& M.S. Sakshi. (2017). "Online Learning". International Education \& Research

Journal 3 (8): 32-34.

Dwirahayu, G.

(2011).

"Implementation of CharacterBuilding Education in Mathematics Teaching and Learning to Create of Human Character." Proceeding of International and the Fourth National Conference on Mathematic Education, 123132.

Erez, R. (2004). "Freedom and Creativity: An Approach to Science Education for Excellent Students and Its Realization in the Israel Arts and Science Academy's Curriculum. The Journal of Secondary Gifted Education 15 (4) 133-140.

Giarrusso, R., Richlin-Klonsky, J., Roy, W. G., \& Strenski, E. (1994). A Guide to Writing Sociology Papers. New York: ST. Martin's Press.

Glaser, B. G., \& Strauss, A. L. (1967). The Discovery of Grounded Theory: Strategies for Qualitative Research. New York: Aldine de Gruyter.

Green, A. W. (1943). "Concept of Responsiblity." Journal of Criminal Law and Criminology, 33(5), 392-394.

Gülten, D. C., Yaman, Y., Deringöl, Y.,
\& Özsari, I. (2011). "Investigating the Relationship between Curiosity level and Computer Self Efficacy Beliefs of Elementary Teachers Candidates." TOJET: The Turkish Online Journal of Educational Technology, 10(4), 248-254.

Hall, S. (1997). Representation: Cultural Representations and Signifying Practices. London: SAGE Productions.

Hasan, M. I. (2002). Pokok-Pokok Materi Metode Penelitian dan Aplikasinya. Bogor: Ghalia Indonesia.

Irfan, M., Kusumaningrum, B., Yulia, Y., \& Widodo, S. A. (2020). "Challenges during the Pandemic: Use of Online Learning in Mathematics Learning in Higher Education." Infinity Journal, 9(2), 147-157. https://doi.org/10.22460/infinit y.v9i2.p147-158

Lenk, H., \& Maring, M. (1999). "Types of Responsibility Conflicts in Science and Technology: An Analysis of codes of Ethics and Responsibility Problems in Engineering." Argumentos de Razón Ténica, 2, 51-68.

Mahyoob, M. (2020). "Challenges of e-Learning during the COVID-19 Pandemic Experienced by EFL Learners." Arab World English Journal, 11(4), 351-362. https://doi.org/10.24093/awej/ vol11no4.23

Marini, A. (2017). "Character Building through Teaching and Learning Process: Lesson in Indonesia." PONTE International 
Vol. 3 No. 2

December 2021

e- ISSN 2685 - 0559

p- ISSN 2684 - 673X

Journal of Science and Research, 73(5), 117-182.

Markey, A., \& Loewenstein, G. (2014). "Curiosity." In R. Pekrun \& L. Linnenbrink-Garcia (Eds.), International Handbook of Emotions in Education. New York: Routledge.

Martin, S. (2007). "Responsibility: A Philosophical Perspective." In G. Dewsbury \& J. Dobson (Eds.), Responsibility and Dependable System. New York: Springer.

Maulana, H. A. (2021). "Psychological Impact of Online Learning during the Covid-19 Pandemic: A Case Study on Vocational Higher Education". Indonesia Journal of Learning Education and Counseling, 3(2), 130-139.

Mohanty, A., Pradhan, R. K., \& Jena, L. K. (2015). "Curiosity and Meaning of Life Leading towards Personal Groeth: The Role of Emotional Intelligence." Journal of the Indian Academy of Applied Psychology, 41(2), 1-10.

Nambiar, D. (2020). "The Impact of Online Learning During the Covid-19: Students' and Teachers' Perspective". The International Journal of Indian Psychology, 8(2), 783-793.

Nichols, Mark, H., Cator, \& Karen. (2008). Challenge Based Learning White Paper. Cupertino, California: Apple, Inc.

Olson, E. (1986). Measurement of Curiosity in Junior High School Students. . Unpublished doctoral dissertation, lowa State University, Ames, lowa, United States.
Pluck, G., \& Helen, J. (2011). "Stimulating Curiosity to Enhance Learning." GESJ: Education Science and Psychology, 2(9), 24-31.

Pokhrel, S., \& Chhetri, R. (2021). “A Literature Review on Impact of COVID-19 Pandemic on Teaching and Learning." Higher Education for the Future, 8(1), 133-141.

https://doi.org/10.1177/234763 1120983481

Ratnasari, W. (2018). "Character Building in Education: $A$ Proposed Theory for STAI's Economic Syari'ah Program." AL-MUQAYYAD: Jurnal Ekonomi Syariah, 1(1), 25-39. https://doi.org/10.46963/jam.v $1 \mathrm{i} 1.48$

Rowson, J., Young, J., Spencer, N., Lindley, E., \& Gecius, E. (2012). The Power of Curiosity: How Linking Inquisitiveness to Innovate Could Help to Address Our Energy Challenges. UK: RSA Social Brain Center.

Sareen, S., \& Nangia, A. (2020). "Teaching during COVID-19: Attitude and Challenge faced by School Teachers". International Journal of Disaster and Business Continuity, 11(1), 3012-3018.

St.Clair, K. L., \& Hackett, P. M. W. (2012). "Academic Challenge: Its Meaning for College Students and Faculty". Journal on Centers for Teaching and Learning, 4, 101-117.

Usman, H., \& Akbar, P. S. (2008). Metodologi penelitian sosial. Jakarta: Bumi Aksara.

Vonderwell, S., \& Savery, J. (2004). 
Vol. 3 No. 2

December 2021

e- ISSN 2685 - 0559

"Online Learning: Student Role and Readiness." Turkish Online Journal of Educational Technology, 3(3), 38-42. http://prx-

keiser.lirn.net/login?qurl=http:/ /search.ebscohost.com/login.as px?direct=true $\& d b=e h h \& A N=14$ $019028 \&$ site $=$ ehost-live

Wehmeier, S. (2000). Oxford Advanced Learner's Dictionary (6th ed.). Oxford: Oxford University Press.

Xu, D., \& Jaggars, S. S. (2013). The Impact of Online Learning on Students' Course Outcomes: Evidence from a Large Community and Technical College System. Economics of Education Review, 37, 46-57. https://doi.org/10.1016/j.econe durev.2013.08.001

Yuliana. (2020). "Corona Virus Disease (Covid-19): Sebuah Tinjauan Literatur." Wellness and Healthy Magazine, 2(1), 187-192.

Yusnilita, N. (2020). "The Impact of Online Learning: Student's View." ETERNAL: English Teaching Journal, 11(1), 57-61. 
Vol. 3 No. 2

December 2021

e- ISSN 2685 - 0559 